\title{
Association between Adhesive Molecules and Oxidative Stress Markers among Non-Insulin Dependent Diabetic Patients
}

\author{
Mohammed H Saiem Al-Dahr* \\ Department of Medical Laboratory Technology, King Abdulaziz University, Saudi Arabia
}

Submission: March 20, 2017; Published: April 27, 2017

"Corresponding author: Mohammed H. Saiem Al-Dahr, Department of Medical Laboratory Technology, King Abdulaziz University, Saudi Arabia, Email: mdahr@kau.edu.sa

\begin{abstract}
Background: Non-insulin dependent diabetes (NIDDM) is usually associated with cardiovascular disorders risk factors.

Objective: This study aimed to detect the association between adhesive molecules and oxidative stress biomarkers among obese NIDDM patients.

Material and Methods: Eighty obese patients with NIDDM (46 males and 34 females). Their age mean was $47.53 \pm 6.81$ year and their body mass index (BMI) ranged from 31 to $35 \mathrm{Kg} / \mathrm{m} 2$ and a control group included eighty healthy volunteers, who were gender and age matched.

Results: Non-insulin dependent diabetes patients showed significantly higher Malondialdehyde (MDA), Superoxide dismutase (SOD), Inter-Cellular Adhesion Molecule (ICAM-1), Vascular Cell Adhesion Molecule (VCAM-1) and E-selection in addition to significantly lower values of Glutathione (GSH) and Glutathione peroxidase (GPX) levels in comparison to controls. Serum levels of ICAM-1, VCAM-1 and E-selection showed a direct relationship with serum MDA and SOD. However, serum levels of ICAM-1, VCAM-1 and E-selection showed an inverse relationship with GSH and GPX.
\end{abstract}

Conclusion: Within the limit of there is an association between adhesive molecules and oxidative stress markers among non-insulin dependent diabetic patients.

Keywords: Non-insulin dependent diabetes mellitus; Obesity; Adhesive molecules; Oxidative stress

Abbreviations: NIDDM: Non-Insulin Dependent Diabetes; BMI: Body Mass Index; MDA: Malondialdehyde; SOD: Superoxide Dismutase; ICAM1: Inter-Cellular Adhesion Molecule; VCAM-1: Vascular Cell Adhesion Molecule; GSH: Glutathione; GPX: Glutathione Peroxidase

\section{Introduction}

Globally, about $6 \%$ of population is affected with diabetes mellitus and by 2030 its prevalence will reach 552 million patients [1]. Non-insulin dependent diabetes mellitus (NIDDM) is characterized by insulin resistance, failure of different body organs as kidneys, eyes, blood vessels and heart [2] which are induced by different mechanisms which are complex and not fully understood; that include the direct toxic effects of hyperglycemia, systemic inflammation and oxidative stress $[3,4]$.

Diabetes mellitus is usually associated with multiple organ damage as diabetic retinopathy, cardiovascular disorders, renal, gastrointestinal and sexual disorders [5,6], where there is an association between cardiovascular disorders and oxidative stress that are induced by systemic inflammation, endothelial dysfunction and abnormal coagulation profile [7-10].

Oxidative stress has an important role in pathogenesis of diabetic complications [11-14] as antioxidant defense is poor that is induced by the metabolic disturbances among NIDDM patients [15]. There seems to be imbalance between oxidant and antioxidant systems in NIDDM patients. These patients are considered to be under oxidative stress because of prolonged exposure to hyperglycemia [16].

Non-insulin dependent diabetes mellitus is usually associated with $\beta$-cell failure, hyper insulinemia and hyperlipidemia that induce endothelial dysfunction and abnormal inflammatory 
markers [17,18]. Insulin has an essential role in regulation of vascular function by stimulation of the vascular cell adhesion molecule (soluble vascular cell adhesion molecule-1 (VCAM1), soluble intercellular cell adhesion molecule-1 (ICAM-1) and E-selectin on expression of endothelium [19-21].

This study aimed to detect the association between adhesive molecules and oxidative stress biomarkers among obese NIDDM patients.

\section{Materials and Methods}

\section{Subjects}

Eighty obese patients with T2DM (46 males and 34 females). The mean of their age was $47.53 \pm 6.81$ year and their body mass index (BMI) ranged from 31 to $35 \mathrm{Kg} / \mathrm{m} 2$, were selected from the out-patient diabetic clinic of the King Abdalziz Teaching Hospital. They were checked for fasting/random glucose levels. Only participants have fasting blood sugar levels more than $5.6 \mathrm{mmol} / \mathrm{l}$ or random blood sugar level more than $7.8 \mathrm{mmol} / \mathrm{l}$ (impaired blood sugar) were included in this study and were further checked for type 2 diabetes mellitus as per recent American Diabetes Association criteria i.e. fasting blood sugar $\geq 7.0 \mathrm{mmol} / \mathrm{l}$ or postprandial blood sugar $\geq 11.1 \mathrm{mmol} / \mathrm{l}$ ( 2 -h plasma glucose $11.1 \mathrm{mmol} / \mathrm{l}$ during an oral glucose tolerance test) and glycosylated hemoglobin $(\mathrm{HbA1c} \%)>6.5 \%$ [22]. Exclusion criteria included smokers, kidney insufficiency, congestive heart failure, pregnant female patients, hepatitis and respiratory failure. Also, eighty apparently healthy, medically free, and treatment naive individuals were recruited to serve as non-diabetic control. All participants signed the informed written consent from.

\section{Laboratory analysis}

5.2.1.Serum glucose, glycosylated hemoglobin, insulin and insulin resistance tests: Hitachi 912 Chemistry Analyzer was used to measure serum glucose using hexokinase reagent from Boehringer Mannheim (Indianapolis, IN 46256). However, AviBion human adiponectin (Acrp 30) was used to measure serum levels of adiponectin. While, a cobas immunoassay analyzer (Roche Diagnostics) was used to measure serum insulin. In addition, homeostasis model assessment (HOMA-IR) was used to detect insulin resistance. HOMA-IR=(fasting blood glucose (mmol/l)_fasting insulin $(\mathrm{mIU} / \mathrm{ml})) / 22.5$ [23]. Assessment of glycosylated hemoglobin (HBA1c\%) was carried out by quantitative chromatographic spectrophotometric determination of glycohemoglobin in whole blood using a HBA1c kit (Bio-Systems).

5.2.2.Adhesive molecules measurements: Biomarkers of endothelial function included adhesion molecules (ICAM-1 and VCAM-1) and soluble E-selectin levels were measured from frozen plasma samples stored at $-80{ }^{\circ} \mathrm{C}$. Enzyme-linked immunosorbent assays kits (ELISAs) were used to measure soluble levels of ICAM1, VCAM-1 and sE-selectin (GE Healthcare Amersham, Biotrak Easy ELISA).

5.2.3.Measurement of oxidative stress markers and antioxidant status: For all participants serum (from $10 \mathrm{~mL}$ blood in plain vial) and plasma (from $5 \mathrm{~mL}$ blood in EDTA vial) were separated from the sample within $30 \mathrm{~min}$ of collection and was stored in pyrogen free polypropylene cryotubes at- $80{ }^{\circ} \mathrm{C}$ until analysis. Oxidative stress was studied by markers of lipid peroxidation included determining plasma levels of malondialdehyde (MDA) was measured by the method as outlined by Esterbauer et al. [24] and were expressed as mmol/L. However, Anti-oxidant status was studied by glutathione (GSH) The reduced GSH level was measured by adopting the method described by Weckbecker \& Cory [25] , glutathione peroxidase (GPx) and superoxide dismutase (SOD) were was estimated according the spectrophotometric method, as described by Masnini [26], which is based on the dismutation of superoxide anion into oxygen and hydrogen peroxide.

\subsection{Statistical analysis}

Independent t-test was used to compare mean differences between both groups. Statistical analysis of data was performed using SPSS (Chicago, IL, USA) version 17. The degree of correlation oxidative stress markers, adhesive molecules in obese NIDDM patients was detected by Pearson's product moment correlation coefficients ( $\mathrm{r}$ ).

\section{Results}

Eighty obese patients with NIDDM and eighty healthy control subjects were enrolled in our study, there was no significant differences in BMI between both groups, in addition, NIDDM patients showed significantly higher serum insulin, Homeostasis Model Assessment-Insulin Resistance (HOMA-IR) index, fasting blood sugar (FBS), postprandial blood sugar (PPS) and glycosylated hemoglobin (HBA1c) levels in comparison to controls (Table 1).

Table 1: Baseline characteristics of NIDDM patients and control subjects.

\begin{tabular}{|c|c|c|c|}
\hline & \multicolumn{2}{|c|}{ Mean +SD } & \multirow{2}{*}{ Significance } \\
\hline & NIDDM Group & Control Group & \\
\hline Age (year) & $47.53 \pm 6.81$ & $48.12 \pm 7.33$ & $\mathrm{P}>0.05$ \\
\hline Gender (M/F) & $46 / 34$ & $48 / 32$ & $P>0.05$ \\
\hline BMI (kg/m2) & $30.85 \pm 3.62$ & $31.24 \pm 3.56$ & $\mathrm{P}>0.05$ \\
\hline Insulin (mU/l) & $15.93 \pm 3.74^{*}$ & $8.51 \pm 2.49$ & $\mathrm{P}<0.05$ \\
\hline FBS (mg/dl) & $185.62 \pm 16.88^{*}$ & $90.13 \pm 8.55$ & $\mathrm{P}<0.05$ \\
\hline PPS (mg/dl) & $243.75 \pm 21.54^{*}$ & $122.98 \pm 14.11$ & $\mathrm{P}<0.05$ \\
\hline HOMA-IR & $6.46 \pm 1.28^{*}$ & $3.12 \pm 1.03$ & $\mathrm{P}<0.05$ \\
\hline HBA1c (\%) & $9.12 \pm 2.79 *$ & $5.94 \pm 1.12$ & $\mathrm{P}<0.05$ \\
\hline
\end{tabular}

BMI: Body Mass Index; FBS: Fasting Blood Sugar; PPS: Postprandial Blood Sugar; HOMA-IR: Homeostasis Model Assessment-Insulin Resistance (HOMA-IR) Index; HBA1c: Glycosylated Hemoglobin;

$\left.{ }^{*}\right)$ indicates a significant difference between the two groups, $P<0.05$. 
Table 2 summarizes the comparison between NIDDM patients and matched controls. Patients with NIDDM showed significantly higher Malondialdehyde (MDA), Superoxide dismutase (SOD), Inter-Cellular Adhesion Molecule (ICAM-1), Vascular Cell Adhesion Molecule (VCAM-1) and E-selectin in addition to significantly lower values of Glutathione (GSH) and Glutathione peroxidase (GPX) levels in comparison to controls (Table 2).

Table 2: Mean value and significance of biochemical parameters of type 2 diabetic patients and control subjects.

\begin{tabular}{|c|c|c|c|}
\hline & \multicolumn{2}{|c|}{ Mean +SD } & \multirow[b]{2}{*}{ Significance } \\
\hline & $\begin{array}{l}\text { Diabetic } \\
\text { Group }\end{array}$ & $\begin{array}{l}\text { Control } \\
\text { Group }\end{array}$ & \\
\hline $\begin{array}{r}\text { MDA } \\
(\mathrm{nM} / \mathrm{mL})\end{array}$ & $0.29 \pm 0.06^{*}$ & $0.13 \pm 0.04$ & $\mathrm{P}<0.05$ \\
\hline $\begin{array}{l}\text { GSH (nM/ } \\
\mathrm{mL})\end{array}$ & $3.58 \pm 0.74^{*}$ & $4.72 \pm 0.85$ & $\mathrm{P}<0.05$ \\
\hline $\begin{array}{l}\text { GPX (UI/ } \\
\text { mL) }\end{array}$ & $2.61 \pm 0.42^{*}$ & $3.83 \pm 0.56$ & $\mathrm{P}<0.05$ \\
\hline $\begin{array}{l}\text { SOD (UI/ } \\
\text { mL) }\end{array}$ & $120.33 \pm 18.72 *$ & $95.91 \pm 14.85$ & $\mathrm{P}<0.05$ \\
\hline $\begin{array}{c}\text { ICAM-1 } \\
\text { (ng/ml) }\end{array}$ & $97.26 \pm 11.51^{*}$ & $78.63 \pm 8.11$ & $\mathrm{P}<0.05$ \\
\hline $\begin{array}{l}\text { VCAM-1 } \\
\text { (ng/ml) }\end{array}$ & $815.53 \pm 47.26^{*}$ & $711.24 \pm 35.19$ & $\mathrm{P}<0.05$ \\
\hline $\begin{array}{l}\text { E-selectin } \\
(\mathrm{ng} / \mathrm{ml})\end{array}$ & $16.25 \pm 3.83^{*}$ & $9.12 \pm 2.52$ & $\mathrm{P}<0.05$ \\
\hline
\end{tabular}

MDA: Malondialdehyde; GSH: Glutathione; GPX: Glutathione Peroxidase SOD: Superoxide Dismutase; ICAM-1 = Inter-Cellular Adhesion Molecule; VCAM-1: Vascular Cell Adhesion Molecule;

$\left.{ }^{*}\right)$ indicates a significant difference between the two groups, $P<0.05$.

Table 3 summarizes the relationship between parameters of oxidative stress and adhesive molecules in NIDDM patients and the healthy control subjects. Serum levels ICAM-1, VCAM-1 and E-selectin showed a direct relationship with MDA and SOD. However, serum levels of ICAM-1, VCAM-1 and E-selectin showed an inverse relationship with GSH and GPX (Table 3).

Table 3: Correlation coefficients test value of the studied variables in the NIDDM group.

\begin{tabular}{|c|c|c|c|}
\hline & $\begin{array}{c}\text { ICAM-1 (ng/ } \\
\mathbf{m l})\end{array}$ & $\begin{array}{c}\text { ICAM-1 (ng/ } \\
\mathbf{m l})\end{array}$ & $\begin{array}{c}\text { E-selectin (ng/ } \\
\mathbf{m l})\end{array}$ \\
\hline $\mathrm{MDA}(\mathrm{nM} / \mathrm{mL})$ & $0.71^{*}$ & $0.59^{*}$ & $0.61^{*}$ \\
\hline $\mathrm{GSH}(\mathrm{nM} / \mathrm{mL})$ & $0.58^{*}$ & $0.64^{*}$ & $0.56^{*}$ \\
\hline $\mathrm{GPX}(\mathrm{UI} / \mathrm{mL})$ & $0.73^{*}$ & $0.75^{*}$ & $0.68^{*}$ \\
\hline $\mathrm{SOD}(\mathrm{UI} / \mathrm{mL})$ & $0.62^{*}$ & $0.57^{*}$ & $0.72^{*}$ \\
\hline
\end{tabular}

MDA: Malondialdehyde; GSH: Glutathione; GPX: Glutathione Peroxidase; SOD: Superoxide Dismutase; ICAM-1: Inter-Cellular Adhesion Molecule; VCAM-1: Vascular Cell Adhesion Molecule; SC: Spearman's correlation was used *: $\mathrm{P}<0.05$.

\section{Discussion}

Currently, non-insulin dependent diabetes mellitus is associated with increased DNA damage due to high level of oxidative stress [27-29]. Our study underscores that patients with non-insulin dependent diabetes mellitus had alteration of adhesive molecules and oxidative stress markers, in addition serum levels of ICAM1, VCAM-1 and E-selectin showed a direct relationship with MDA and SOD. However, serum levels of ICAM-1, VCAM-1 and E-selectin showed an inverse relationship with GSH and GPX.

In the present study VCAM-1, ICAM-1 and E-selectin level were higher in NIDDM patients than the healthy control subjects. Therefore, the results in this study are consistent with Meigs et al. [30] stated that women with NIDDM had endothelial dysfunction [30]. In addition, Thorand et al. [31] believed that endothelial dysfunction has a role in NIDDM pathogenesis [31]. However, level of sE-selectin was independently associated with diabetes mellitus [32,33]. Ferri et al. [34] found that obese subjects had higher concentration of sVCAM-1, sICAM-1, and E-selection than normal body weight subjects [34].

The exact mechanism of endothelial dysfunction associated with T2DM may due to insulin resistance that induces reduction of dihydropterin reductase activity along with depletion of Tetrahydrobiopterin that is an important co-factor for the catalytic activity of Nitrous Oxides (NOS) [35-39]. Moreover, abnormal blood lipids profile is another possible mechanism for endothelial dysfunction induced by insulin resistance in patients with NIDDM $[40,41]$.

In the present study type 2 diabetes patients showed significantly higher MDA and SOD in addition to significantly lower values of GSH and GPX levels in comparison to normal control subjects. Our results agreed with Kumawat et al. [42] stated that GSH significantly reduced and MDA significantly increased in diabetic patients. A similar study by Kavitha et al [43] showed that diabetic patients had increased level of MDA.

\section{Conclusion}

Within the limit of there is an association between adhesive molecules and oxidative stress markers among NIDDM patients.

\section{Acknowledgment}

This project was funded by the Deanship of Scientific Research (DSR), King Abdulaziz University, Jeddah, under grant no. (31-1421437-G). The authors, therefore, acknowledge with thanks DSR technical and financial support.

\section{References}

1. IDF (2011) IDF Diabetes Atlas. International Diabetes Federation, Belgium.

2. American Diabetes Association (2010) Diagnosis and classification of diabetes mellitus. Diabetes Care 33(Suppl 1): S62-S69.

3. Lebeche D, Davidoff AJ, Hajjar RJ (2008) Interplay between impaired calcium regulation and insulin signaling abnormalities in diabetic cardiomyopathy. Nat Clin Pract Cardiovasc Med 5(11): 715-724. 
4. Pu LJ, Lu L, Xu XW, Zhang RY, Zhang Q, et al. (2006) Value of serum glycated albumin and high-sensitivity C-reactive protein levels in the prediction of presence of coronary artery disease in patients with type 2 diabetes. Cardiovasc Diabetol 5: 27.

5. Cade WT (2008) Diabetes-related microvascular and macrovascular diseases in the physical therapy setting. Phys Ther 88(11): 1322-1335.

6. Rahman S, Rahman T, Ismail AA, Rashid ARA (2007) Diabetesassociated macrovasculopathy: pathophysiology and pathogenesis. Diabetes Obes Metab 9(6): 767-780.

7. Dincer Y, Akcay T, Alademir Z, Ilkova H (2002) Effect of oxidative stress on glutathione pathway in red blood cells from patients with insulindependent diabetes mellitus. Metabolism 51(10): 1360-1362.

8. Serdar Z, Aslan K, Dirican M, Sarandol E, Yesilbursa D, et al. (2006) Lipid and protein oxidation and antioxidant status in patients with angiographically proven coronary artery disease. Clin Biochem 39(8): 794-803.

9. Tracy RP (2003) Thrombin, inflammation and cardiovascular disease: an epidemiologic perspective. Chest 124(3 Suppl): 49S-57S.

10. Al-Aubaidy HA, Jelinek HF (2011) Oxidative DNA damage: antioxidant response in postprandial hyperglycaemia in type 2 diabetes mellitus. Br J Diabetes Vasc Dis 11: 87-91.

11. Matough FA, Budin SB, Hamid ZA, Alwahaibi N, Mohamed J (2012) The role of oxidative stress and antioxidants in diabetes complications. Sultan Qaboos Univ J 12(1): 5e-e18.

12. Pan HZ, Zhang L, Guo MY, Sui H, Li H, et al. (2010) The oxidative stress status in diabetes mellitus and diabetes nephropathy. Acta Diabetol 47(Suppl): 71-76.

13. Odum EP, Ejilemele AA, Wakwe VC (2012) Antioxidant status of type 2 diabetic patients in Port Harcourt, Nigeria. Niger J Clin Pract 15(1): 55-58.

14. Shi YC, Pan TM (2012) Red mold, diabetes, and oxidative stress: A review. Appl Microbiol Biotechnol 94(1): 47-55.

15. Lima V, Sampaio F, Bezerra D (2011) Parameters of glycemic control and their relationship with zinc concentrations in blood and with superoxide dismutase enzyme activity in type 2 diabetes patients. Arq Bras Endocrinol Metab 55: 701-707.

16. Likidlilid A, Patchanans N, Peerapatdit T, Sriratanasathavorn C (2010) Lipid peroxidation and antioxidant enzyme activities in erythrocytes of type 2 diabetes patients. J Med Assoc Thai 93(6): 682-693.

17. Gómez JM, Vila R, Catalina P, Soler J, Badimón L, et al. (2008) The markers of inflammation and endothelial dysfunction in correlation with glycated haemoglobin are present in type 2 diabetes mellitus patients but not in their relatives. Glycoconj J 25(6): 573-579.

18. Ansar S, Koska J, Reaven PD (2011) Post prandial hyperlipidemia, endothelial dysfunction and cardiovascular risk: focus on in cretins. Cardiovasc Diabetol 10: 61

19. Cersosimo E, DeFronzo RA (2006) Insulin resistance and endothelial dysfunction: the road map to cardiovascular diseases. Diabetes Metab Res Rev 22(6): 423-436.

20. Endemann DH, Schiffrin EL (2004) Endothelial dysfunction. J Am Soc Nephrol 15(8): 1983-1992.

21. Gómez JM, Sahún M, Vila R, Domènech $P$, Catalina $P$, et al. (2007) Elevation of E-selectin concentrations may correlate with potential endothelial dysfunction in individuals with hypopituitarism during therapy with growth hormone. Curr Neurovasc Res 4(1): 55-62.

22. American Diabetes Association (2010) Diagnosis and classification of diabetes mellitus. Diabetes Care 33(Suppl 1): S62-S69.
23. Matthews DR, Hosker JP, Rudenski AS, Naylor BA, Treacher DF, et al. (1985) Homeostasis model assessment: insulin resistance and beta cell function from plasma FBS and insulin concentrations in man. Diabetologia 28(7): 412-419.

24. Esterbauer H, Gebicki J, Puhl H, Jürgens G (1992) The role of lipid peroxidation and antioxidants in oxidative modification of LDL. Free Radic Biol Med 13(4): 341-390.

25. Weckbecker G, Cory JG (1988) Ribonucleotide reductase activity and growth of glutathione-depleted mouse leukemia L 1210 cells in vitro. Cancer Lett 40(3): 257-264.

26. Masnini M (1988) Determination of superoxide dismutase activity with an electrochemical oxygen probe. Analyt Chim Acta 211: 195-204.

27. Matough FA, Budin SB, Hamid ZA, Alwahaibi N, Mohamed J (2012) The role of oxidative stress and antioxidants in diabetes complications. Sultan Qaboos Univ J 12(1): 5-18.

28. Tatsch E, Bochi GV, Piva SJ, De Carvalho JA, Kober H, et al. (2012) Association between DNA strand breakage and oxidative, inflammatory and endothelial biomarkers in type 2 diabetes. Mutat Res 732(1-2): 1620.

29. Mauricio MD, Aldasoro M, Ortega J, Vila JM (2013) Endothelial dysfunction in morbid obesity. Curr Pharm Des 19(32): 5718-5729.

30. Meigs JB, Hu FB, Rifai N, Manson JE (2004) Biomarkers of endothelial dysfunction and risk of type 2 diabetes mellitus. JAMA 291(16): 19781986.

31. Thorand B, Baumert J, Chambless L, Meisinger C, Kolb H, et al. (2006) Elevated markers of endothelial dysfunction predict type 2 diabetes mellitus in middle-aged men and women from the general population. Arterioscler Thromb Vasc Biol 26(2): 398-405.

32. Song Y, Manson JE, Tinker L, Rifai N, Cook NR, et al. (2007) Circulating levels of endothelial adhesion molecules and risk of diabetes in an ethnically diverse cohort of women. Diabetes 56(7): 1898-1904.

33. Laaksonen DE, Niskanen L, Nyyssönen K, Punnonen K, Tuomainen TP, et al. (2004) C-reactive protein and the development of the metabolic syndrome and diabetes in middle-aged men. Diabetologia 47(8): 14031410 .

34. Ferri C, Desideri G, Valenti M, Bellini C, Pasin M, et al. (1999) Early upregulation of endothelial adhesion molecules in obese hypertensive men. Hypertension 34(4 Pt 1): 568-573.

35. Shinozaki K, Hirayama A, Nishio Y, Yoshida Y, Ohtani T, et al. (2001) Coronary endothelial dysfunction in the insulin-resistant state is linked to abnormal pteridine metabolism and vascular oxidative stress. J Am Coll Cardiol 38(7): 1821-1828.

36. Scherrer U, Randin D, Vollenweider P, Vollenweider L, Nicod P (1994) Nitric oxide release accounts for insulin's vascular effects in humans. J Clin Invest 94(6): 2511-2515.

37. Steinberg HO, Brechtel G, Johnson A, Fineberg N, Baron AD (1994) Insulin mediated skeletal muscle vasodilation is nitric oxide dependent: a novel action of insulin to increase nitric oxide release. J Clin Invest 94(3): 1172-1179.

38. Williams SB, Cusco JA, Roddy MA, Johnstone MT, Creager MA (1996) Impaired nitric oxide-mediated vasodilation in patients with noninsulin-dependent diabetes mellitus. J Am Coll Cardiol 27(3): 567-574.

39. Baron AD, Steinberg HO, Chaker H, Leaming R, Johnson A, et al. (1995) Insulin-mediated skeletal muscle vasodilation contributes to both insulin sensitivity and responsiveness in lean humans. J Clin Invest 96(2): 786-792.

40. Malmström R, Packard CJ, Caslake M, Bedford D, Stewart P, et al. (1997) Defective regulation of triglyceride metabolism by insulin in the liver in NIDDM. Diabetologia 40(4): 454-462. 
41. Mäkimattila S, Liu ML, Vakkilainen J, Schlenzka A, Lahdenperä S, et al. (1999) Impaired endothelium-dependent vasodilatation in NIDDM: relation to LDL size, oxidized LDL and antioxidants. Diabetes Care 22(6): 973-981.

42. Kumawat M, Pahwa M, Gahlaut V, Singh N (2009) Status of antioxidant enzymes and lipid peroxidation in Type 2 diabetes mellitus with micro vascular complications. The Open Endocrinology Journal 3: 12-15.
43. Kavitha G, Ramani G, Dhass P, Aruna R (2011) Oxidative stress, interleukin (IL-6) and atherogenic index of plasma in diabetic nephropathy. International Journal of Applied Biology and Pharmaceutical Technology 2(2): 211-216.

\section{Your next submission with Juniper Publishers will reach you the below assets}

- Quality Editorial service

- Swift Peer Review

- Reprints availability

- E-prints Service

- Manuscript Podcast for convenient understanding

- Global attainment for your research

- Manuscript accessibility in different formats

( Pdf, E-pub, Full Text, Audio)

- Unceasing customer service

Track the below URL for one-step submission https://juniperpublishers.com/online-submission.php 